\title{
High tick abundance and diversity of tick-borne pathogens in a Finnish city
}

\author{
Tero Klemola ${ }^{1}$ (D) • Jani J. Sormunen ${ }^{1,2} \cdot$ Janka Mojzer $^{1} \cdot$ Satu Mäkelä ${ }^{1}$ • Eero J. Vesterinen ${ }^{2,3}$
}

Published online: 15 April 2019

(C) The Author(s) 2019

\begin{abstract}
The sheep tick Ixodes ricinus is the primary vector for various zoonotic diseases, including Lyme borreliosis and tick-borne encephalitis (TBE), in Europe. Because both abundance of ticks and prevalence of tick-borne pathogens in these organisms have increased in many locations and under different environments, we designed a study to survey the occurrence of ticks and pathogens in an urban area, namely, the city of Turku, in SW Finland. In summer 2017, we collected $>700$ ticks, primarily from city parks, suburban forest patches, and recreational areas. Comprehensive subsets of ticks were screened for presence of all common tick-borne pathogens. Half of the ticks carried at least one pathogen. The most common pathogens detected were the causative agents of Lyme borreliosis, i.e., bacteria belonging to the Borrelia burgdorferi sensu lato group. Their prevalence was $37 \%$ in nymphal and $47 \%$ in adult ticks, which are high in comparison with surveys conducted elsewhere in northern Europe. Similarly, Rickettsia spp. (primarily R. helvetica) were also detected in a relatively high proportion of the samples (11\% of both nymphs and adults). The TBE virus was not found in a relatively small subsample, but we detected (albeit at a low prevalence of 0-6\% of nymphs and adults) the bacterial pathogens Borrelia miyamotoi, Anaplasma phagocytophilum and Candidatus Neoehrlichia mikurensis and the protozoan Babesia spp., which are also known agents of zoonotic diseases. The relatively high abundance of ticks and high diversity and overall prevalence of tick-borne pathogens suggest a lively and dense presence of mammalian and avian tick hosts in the city. Our results indicate a higher risk of encountering tick-borne pathogens in urbanized areas of southern Finland than previously known. Moreover, the possibility of acquiring tick-borne diseases from urban environments likely exists throughout most of Europe, and it should be acknowledged by health care professionals.
\end{abstract}

Keywords Borrelia $\cdot$ Ixodes ricinus $\cdot$ Rickettsia $\cdot$ Tick-borne pathogens $\cdot$ Tick hosts $\cdot$ Urban ecology

\section{Introduction}

Zoonotic diseases (or zoonoses) are infections that are transmitted from animals to humans. The emergence of many such diseases is linked to globalization, urbanization, and climate change (Mills et al. 2010; Hassell et al. 2017). Because

Electronic supplementary material The online version of this article (https://doi.org/10.1007/s11252-019-00854-w) contains supplementary material, which is available to authorized users.

Tero Klemola

tero.klemola@utu.fi

1 Department of Biology, University of Turku, FI-20014 Turku, Finland

2 Biodiversity Unit, University of Turku, Turku, Finland

3 Department of Agricultural Sciences, University of Helsinki, Helsinki, Finland transmission of such diseases requires a contact, or an arthropod vector, between an infected animal and a human, zoonoses are prone to establish in densely populated urban areas, if such urban environments can also sustain rich communities of animal hosts and vectors of the pathogens.

The broadly distributed sheep tick Ixodes ricinus (Acari: Ixodidae) is a primary vector for the causative agents (bacteria, viruses and protozoans) of various diseases affecting humans and domestic and companion animals in western Eurasian (Pfäffle et al. 2013; Rizzoli et al. 2014; EstradaPeña et al. 2017). Of these diseases, borreliosis (= Lyme disease) and tick-borne encephalitis (TBE) are considered the most serious for public health. Both the abundance of ticks and the numbers of diagnosed tick-borne diseases have increased in many European countries in recent decades (e.g., Jaenson et al. 2012; Sajanti et al. 2017). Not all of the reasons for these increases have been explored, but a substantial role for the changing climate has commonly been emphasized (e.g., Jaenson et al. 2012; Medlock et al. 2013; Estrada-Peña 
and de la Fuente 2014; Jore et al. 2014; Medlock and Leach 2015; Alkishe et al. 2017). Warmer winters, prolonged growing season and other climatic changes are suggested to have direct effects on tick and pathogen performance and indirect effects on tick dynamics via density and range shifts in host animal populations.

In Finland (Fig. 1), ticks and tick-borne diseases are recognized as threats, especially in the Åland Islands between Finland and Sweden, as well as in other archipelagos and coastal areas of the Baltic Sea, the area in which research has primarily been directed (Wahlberg et al. 1989; Mäkinen et al. 2003; Alekseev et al. 2007; Wilhelmsson et al. 2013a, b; Lindblom et al. 2016). Since 2000, however, it has become clear that ticks and health problems due to tick-borne diseases are no longer delimited to particular island biotopes or coastal regions of the country. Ultimately, a national crowdsourced tick collection campaign in 2015 confirmed that both I. ricinus and I. persulcatus (the taiga tick) are widespread and can carry pathogens across their large distribution ranges up to the Arctic Circle (Laaksonen et al. 2017, 2018).

Of the 20,000 ticks sent to researchers by residents (Laaksonen et al. 2017), a large portion of them originated from urbanized areas near cities and towns in the southern part of Finland, which was expected to reflect the denser human population of these regions and thereby conceal the actual tick abundance in different environments and geographical locations. However, even a relatively low tick abundance can be an important source of human pathogen exposure in urban and suburban recreational areas, semi-natural forest patches, and, for example, maintained city parks due to the high numbers of possible contacts between humans and ticks (Rizzoli et al. 2014; Paul et al. 2016). Numerous investigations conducted in urbanized areas (reviewed in Rizzoli et al. 2014), for example in Helsinki (Finland), Budapest (Hungary), Košice (Slovakia), Warsaw (Poland), and near Paris (France), have indicated well-established tick populations with a corresponding, or even a higher, prevalence of tick-borne pathogens when compared to the endemic, more natural areas nearby (Junttila et al. 1999; Földvári et al. 2011; Pangrácová et al. 2013; Paul et al. 2016; Kowalec et al. 2017).

Tick observations in cities indicate that abundant and species-rich mammalian and/or avian faunae inhabit urbanized areas. Ticks at the adult stage blood-feed on mediumand large-sized mammals, while small mammals and ground-feeding song birds serve as maintenance hosts for larval and nymphal stages. Small rodents (e.g. voles, mice, and squirrels), hedgehogs, and shrews are common in urban areas and are known to circulate tick-borne pathogens there, meaning that they are recognized pathogen-reservoir hosts of I. ricinus (Rizzoli et al. 2014).

The current tick-sampling study was conducted in the city of Turku $\left(60^{\circ} 27^{\prime} \mathrm{N}, 22^{\circ} 15^{\prime} \mathrm{E}\right.$; population 320,000 in the Turku region and 200,000 within the city), SW Finland, in the early summer of 2017 to examine how urbanized

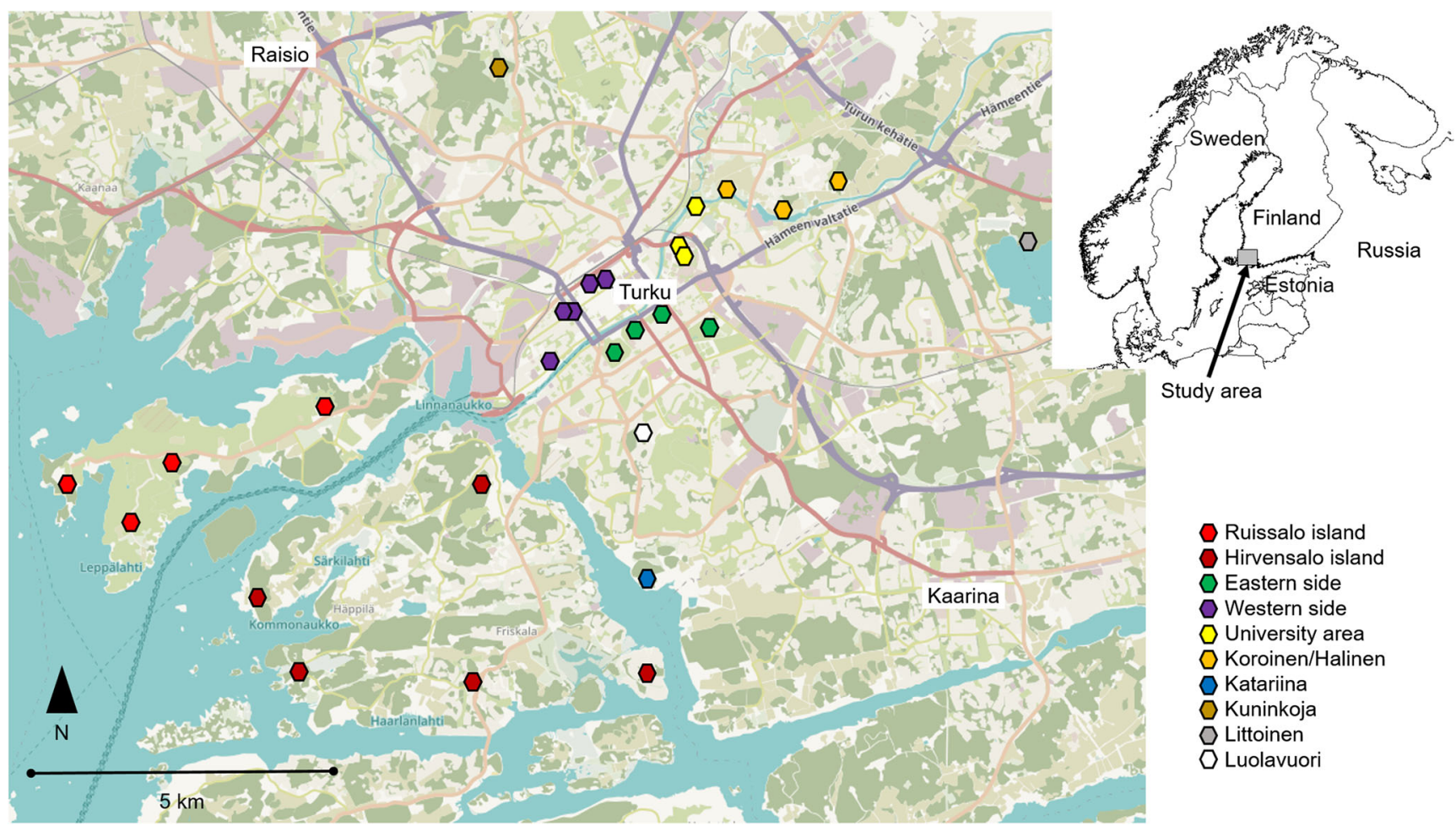

Fig. 1 Tick sampling in the city of Turku, SW Finland, in the summer of 2017. The symbols denote cloth-dragging sites (Online Resource 1) as grouped into nine study areas by their colour. (C) OpenStreetMap 
landscapes such as city parks, yards, suburban forest patches, and recreational areas are hosting Ixodes ticks, and whether the pathogen prevalence of these ticks differs from that of the ticks occupying the more rural, natural landscapes nearby (Sormunen et al. 2016a, b, c, 2018). Comparisons to two earlier tick samplings that were conducted in the city of Turku [in the summer of 2000 (Mäkinen et al. 2003) and the summer of 2013 (Sormunen et al. 2016b, c)] revealed that I. ricinus emerged and is currently also present in urban city parks within $(1 \mathrm{~km})$ of the city centre and that the tick abundance has manifoldly increased since the year 2000 in two suburban islands used for recreational activities. The current study also reports remarkably high Borrelia burgdorferi sensu lato (the causative agent for Lyme borreliosis) prevalence as well as several recently emerged pathogens that were unobserved, or unstudied, during earlier city investigations (Mäkinen et al. 2003; Sormunen et al. 2016b, c).

\section{Material and methods}

\section{Study areas and tick sampling}

Tick sampling was conducted in ten distinct areas, all located in the city of Turku (Fig. 1), between late May and early July of 2017. Five of the areas (hereafter "primary study areas") were sampled four times at weekly or biweekly intervals, whereas another five (hereafter "secondary") areas were visited only twice. The data tabulated in Online Resource 1 describe the study area and exact study sites within the areas, as well as dates of sampling.

Two of the study areas were suburban islands (Ruissalo and Hirvensalo, which were a primary and secondary study area, respectively) that were also monitored in earlier city investigations (Mäkinen et al. 2003; Sormunen et al. 2016b, c). Eight other study areas were located on the mainland. Urban city parks, yards and vegetation-flanked walkways in the gridplanned city centre of Turku were divided into eastern and western sides using the Aura River (Fig. 1), forming one primary study area each. One primary study area was established within the main campus area of the University of Turku, while the fifth one was close to housing estates in Koroinen/Halinen (Fig. 1). Two city parks on the eastern side of the city, Urheilupuisto and Samppalinna, were also sampled during earlier studies (Mäkinen et al. 2003; Sormunen et al. 2016b, c).

In addition to Hirvensalo Island, the suburban areas Katariina, Kuninkoja, Littoinen and Luolavuori were visited twice during the sampling period and were thus considered as secondary areas. Although all these areas also contain walking/ jogging/nature trails for recreational purposes, the primary study area Ruissalo Island is by far the most popular district of the city for many types of outdoor activities, such as walking, jogging, biking, golfing, berry-picking, bird-watching, swimming, camping, and music festivals, and it is visited by hundreds of thousands of people annually. All five primary and one secondary (Hirvensalo Island) study areas consisted of 3-5 nearby but separate study sites (Fig. 1; Online Resource 1). In the other four secondary areas, only one site was studied.

In the study sites, collection of questing ticks was conducted using a cloth-dragging method, in which a $1-\mathrm{m}^{2}$ white cotton cloth was dragged through ground vegetation at a slow walking pace. Ticks that attached to the cloth were counted according to their developmental stage (larva, nymph, adult male or adult female) every ten metres, and all ticks caught using this method were preserved in ethanol-filled Eppendorf tubes and stored at $-20^{\circ} \mathrm{C}$ for further analyses. Cloth-dragging was always conducted in dry weather from 8:00-16:00. Actual 10-m dragging transects within sites were not marked and thus were not exactly the same over consecutive sampling sessions. In most instances, 200-300 m (i.e., 20-30 drags) were dragged during a sampling session (mean $270 \mathrm{~m}$; range $100-600 \mathrm{~m}$ ). According to current knowledge, I. ricinus is the only exophilic Ixodes species occurring in the study area. We have not previously sampled (Sormunen et al. 2016a, b, c, 2018) I. persulcatus individuals or identified them from crowd-sourced material (Laaksonen et al. 2017, 2018) from the Turku region.

\section{Laboratory work}

From the 706 sampled I. ricinus, a comprehensive subsample of 449 ticks was almost immediately screened after collection (in June-July 2017) for presence of bacterial and protozoan pathogens of human or veterinary importance. This subsample included eight $I$. ricinus larvae, 388 nymphs, 28 adult males and 25 adult females. Most (95\%) larvae from all the study areas and a random selection of nymphs from Ruissalo Island remained unscreened at that stage.

Total DNA was extracted from ticks in the first subsample using NucleoSpin ${ }^{\circledR}$ Tissue kits (Macherey-Nagel, Germany) according to the kit protocols (Rev. 13/March 2014). Extracted DNA was stored at $-20^{\circ} \mathrm{C}$ until analysis.

Ticks in the subsample were analysed for presence of $B$. burgdorferi s.l. spirochetes, including genospecies B. afzelii, B. burgdorferi s.s., B. garinii, and some unconfirmed ones. The latter group may still contain individuals from the abovementioned or other genospecies; for example, $B$. valaisiana has recently been detected from tick samples collected in the Turku region (Laaksonen et al. 2018). This non-specificity results from the analysis method, which was not specifically aimed at the genospecies level (see below). In addition, the presence of Borrelia miyamotoi (a tick-borne relapsing fever spirochete), Anaplasma phagocytophilum (a bacterium that causes human granulocytic anaplasmosis), Rickettsia spp. (a bacterium that causes spotted fever), Candidatus Neoehrlichia mikurensis (a bacterium that causes 
neoehrlichiosis), Bartonella spp. (a bacterium that causes many issues, for example, cat scratch disease), and Babesia spp. (a protozoan that causes babesiosis) were analysed.

Another subsample of 157 ticks was selected in May of 2018 to analyse presence of TBE virus (TBEV). These samples included 3 larvae, 147 nymphs and 7 adults. Most (146/ 157) of these ticks were collected from Ruissalo Island, while the rest (11/157) were from the university's main campus area. The presence of bacterial and protozoan pathogens was not addressed in this subsample. Ticks in the second subsample were processed using NucleoSpin 96 RNA kits and RNA/ DNA buffer sets (Macherey-Nagel, Düren, Germany) according to the kit protocols (RNA Kit: Rev. 05 April 2014 and RNA/DNA buffer set: Rev. 08 May 2014). RNA was stored at $-80^{\circ} \mathrm{C}$ and DNA was stored at $-20^{\circ} \mathrm{C}$ until analysis.

The bacterial pathogens B. burgdorferi s.l., B. miyamotoi, A. phagocytophilum, Rickettsia spp., and $C$. N. mikurensis and the protozoan pathogens Babesia spp. in tick samples were screened using real-time quantitative PCR (qPCR) as described before (Sormunen et al. 2016b, c, 2018; Laaksonen et al. 2018). All DNA samples were analysed using three replicate reactions performed in 384-well plates. At least three blank water samples were used as negative controls in each assay. The samples were considered positive only when a successful amplification was detected in all three replicate reactions. Samples that were identified as positive for Babesia and Rickettsia were subsequently sequenced to determine the species, as described before (Laaksonen et al. 2018; Sormunen et al. 2018).

For the B. burgdorferi s.l. genospecies identification, two genospecies-specific duplex assays were used, with one for B. miyamotoi and B. garinii (Bmi/Bga) and another for B. afzelii and B. burgdorferi s.s. (Baf/Bbss) (Online Resource 2 ; Tveten 2013). For Bmi/Bga, we used an $8 \mu \mathrm{L}$ reaction volume, and it contained $4 \mu \mathrm{L}$ of SensiFAST Probe Lo-ROX Kit (Bioline, Germany), $200 \mathrm{nM}$ Bmi primer, $300 \mathrm{nM}$ Bga primer, $100 \mathrm{nM}$ Bmi probe, $150 \mathrm{nM}$ Bga probe and $3 \mu \mathrm{L}$ of DNA template. Assays for Baf/Bbss were likewise run in $8 \mu \mathrm{L}$ total volumes, containing $4 \mu \mathrm{L}$ of SensiFAST Probe Lo-ROX kit, $200 \mathrm{nM}$ Baf primer, $300 \mathrm{nM}$ Bbss primer, $100 \mathrm{nM}$ Baf probe, $150 \mathrm{nM}$ Bbss probe and $3 \mu \mathrm{L}$ of DNA template. Samples that were not found to be positive during either duplex assay were placed in the unconfirmed category.

The thermal cycling profile used for the Bmi/Bga and Baf/ Bbss assays started at $95^{\circ} \mathrm{C}$ for $5 \mathrm{~min}$, followed by 50 cycles of $95^{\circ} \mathrm{C}$ for $10 \mathrm{~s}$ and $60^{\circ} \mathrm{C}$ for $30 \mathrm{~s}$. Thermal cycling was performed at the Finnish Microarray and Sequencing Centre (FMSC, Turku, Finland) using a QuantStudio ${ }^{\mathrm{TM}}$ 12K Flex Real-Time PCR System (Life Technologies Inc., Carlsbad, CA, USA). All qPCR results were analysed using QuantStudio $^{\mathrm{TM}}$ 12K Flex Software v.1.2.2.

Tick-borne encephalitis virus RNA was screened by realtime reverse transcription-PCR as described by Schwaiger and
Cassinotti (2003) and modified by Laaksonen et al. (2017). All samples were run in triplicate at the FMSC using the QuantStudio $^{\text {TM }}$ 12K Flex Real-Time PCR System. Water samples were used as blank controls in each PCR batch. Additionally, multiple strains of TBEV RNA were used as positive controls in each batch of reactions to confirm specificity. Positive control samples emitted strong signals during each reaction.

\section{Statistical analyses}

We refrained from performing formal analyses of the differences in tick abundance among the sampling areas, because the null hypothesis regarding equal abundance is redundant to start with; no plausible biological arguments would lead us to expect the same quantity of ticks in very different types of urban and suburban biotopes.

Reasonably high numbers of samples and positive pathogen findings among the nymphs, however, enabled comparisons related to the prevalence of $B$. burgdorferi s.l. (three confirmed genospecies were pooled with the positives of unconfirmed genotypes), Rickettsia spp., and A. phagocytophilum between island and mainland samples. We chose to pool the samples from the islands and the mainland for statistical tests because sufficiently large sample sizes were not obtained from individual areas, apart from Ruissalo Island and the university campus study areas. In addition, suburban Ruissalo and Hirvensalo Islands can be viewed as passages to the rural, more natural and endemic tick areas of the Turku Archipelago (Mäkinen et al. 2003; Sormunen et al. 2016a), enabling an interesting comparison to the highly structured areas on the mainland.

The probability that a nymph will be positive for B. burgdorferi s.1. (or for Rickettsia spp. or A. phagocytophilum in separate models) was modelled using a generalized linear model (GLM) with binary error distribution and a logit link function. The island-mainland classification was the only fixed explanatory factor. No random factors were set. Model-derived, mean probability estimates with their asymmetric $95 \%$ confidence intervals are given throughout the results. The GLMs were run with the GLIMMIX procedure in SAS v. 9.4 (Stroup 2013).

\section{Results}

\section{Tick abundance}

From $24 \mathrm{~km}$ of cloth-dragged sampling routes, 706 I. ricinus ticks (i.e., 2.94 individuals per $100 \mathrm{~m}^{2}$ ) were sampled from the urban and suburban areas of Turku city. Online Resource 1 tabulates tick abundance data by study areas, by study sites within areas and by tick development stages. As expected, tick 
abundance varied greatly among study areas and varied considerably among sites from the same area. The highest tick density index was obtained from Ruissalo Island (Table 1), and generally, the island sites hosted more ticks than those of most of the mainland sites, although the campus area of the University of Turku was an exception among the mainland areas; a relatively high tick density index was obtained there (Table 1). No ticks were caught on short-mown lawns at any site, but ticks were present, for example, on the grassy edges of city parks, the grassy sides of walkways and the uncared-for "backyards" of the university campus area along with suburban forest patches.

In general, nymphs were the most frequently sampled developmental stage, while adults were dragged in relatively low numbers (Table 1; Online Resource 1). High numbers of larvae were counted in some of the drags on some days, indicating the clumped spatial and temporal distribution of the larval stage. The high number of larvae partially explains the relatively high tick density index in the university campus area (Table 1; Online Resource 1).

\section{Prevalence of pathogens}

Half (223/449) of the screened ticks carried at least one bacterial or protozoan pathogen; co-occurrences of pathogens were also frequent. The most common pathogens were those belonging to the $B$. burgdorferi s.l. group, which consisted, at the least, of the confirmed genospecies $B$. afzelii, B. burgdorferi s.s. and B. garinii (Fig. 2). Over half (15/25, i.e., $60 \%$ ) of the females, approximately $39 \%$ of the males (11/ $28)$ and $36.6 \%$ of the nymphs (142/388) were positive for one of the three confirmed or unconfirmed genospecies of
B. burgdorferi s.1. (Fig. 2). One larva was also found to carry B. burgdorferi s.l. bacteria.

Both the protozoan parasite Babesia spp. and the bacterium $C$. N. mikurensis were infrequently detected in the samples, and the latter was only found in the nymphal stage (Fig. 2). The relapsing fever bacterium B. miyamotoi was also rare; two positives were found among the nymphs and one among adult females (Fig. 2). Rickettsia spp. was a relatively common pathogen and was observed in almost equal prevalence (11$12 \%$ ) at all life stages (but note that only eight larvae were screened). The overall prevalence of A. phagocytophilum was approximately $4 \%$, and it was occasionally observed in both the nymphal and adult samples (Fig. 2). All samples were negative for Bartonella spp. in the first subsample and for TBEV in the second subsample, when these pathogens were analysed. Sequencing was successfully performed for $4 / 6$ Babesia and 39/50 Rickettsia-positive samples. All the Babesia were identified as B. venatorum and all the Rickettsia were R. helvetica.

The probability of identifying a $B$. burgdorferi s.l.-positive sample was higher [0.388 (95\% CI: 0.336-0.443)] in the island nymph samples compared to those from the mainland $[0.258$ (95\% CI: 0.166-0.376)] (GLM: $\mathrm{F}_{1,386}=3.95, P=0.048$ ). This difference was primarily caused by $B$. garinii, which was rare on the mainland but relatively frequent in island samples (Table 2). The other identified B. burgdorferi s.l. genospecies and the unconfirmed ones were almost equally likely to appear in both island and mainland samples (Table 2).

The probability that a nymph would be positive for Rickettsia spp. was lower in the island $[0.093$ (95\% CI: $0.066-0.131)]$ than that in the mainland $[0.197(95 \% \mathrm{CI}$ : $0.118-0.311)]$ samples (GLM: $F_{1,385}=5.67, P=0.018$ ).

Table 1 Sampling effort (cloth-dragged in metres) and density indices (individuals per $100 \mathrm{~m}^{2}$ ) of Ixodes ricinus ticks in urban and suburban areas of Turku city, SW Finland, from late May to early July in 2017

\begin{tabular}{|c|c|c|c|c|c|c|}
\hline Area & Dragged (m) & Larvae & Nymphs & Males & Females & Stages pooled \\
\hline \multicolumn{7}{|l|}{ Islands } \\
\hline Ruissalo, suburban & 3330 & 1.74 & 11.89 & 0.27 & 0.33 & 14.23 \\
\hline Hirvensalo, suburban & 1070 & 0.00 & 1.78 & 0.37 & 0.19 & 2.34 \\
\hline Islands total & 4400 & 1.32 & 9.43 & 0.30 & 0.30 & 11.34 \\
\hline \multicolumn{7}{|l|}{ Mainland } \\
\hline Eastern side of the city, urban & 5030 & 0.00 & 0.14 & 0.04 & 0.02 & 0.20 \\
\hline Western side of the city, urban & 5080 & 0.02 & 0.14 & 0.00 & 0.02 & 0.18 \\
\hline University area, urban & 4050 & 2.79 & 0.86 & 0.22 & 0.17 & 4.05 \\
\hline Koroinen/Halinen, suburban & 3570 & 0.00 & 0.36 & 0.06 & 0.06 & 0.48 \\
\hline Katariina, suburban & 450 & 0.00 & 0.67 & 0.44 & 0.22 & 1.33 \\
\hline Kuninkoja, suburban & 410 & 0.00 & 0.00 & 0.00 & 0.00 & 0.00 \\
\hline Littoinen, suburban & 500 & 0.00 & 0.00 & 0.00 & 0.00 & 0.00 \\
\hline Luolavuori, suburban & 500 & 0.00 & 0.20 & 0.00 & 0.00 & 0.20 \\
\hline Mainland total & 19,590 & 0.58 & 0.34 & 0.08 & 0.06 & 1.06 \\
\hline Total & 23,990 & 0.72 & 2.01 & 0.12 & 0.10 & 2.94 \\
\hline
\end{tabular}


However, the probability of finding A. phagocytophilum did not differ between the island [0.037 (95\% CI: 0.021-0.065)] and mainland [0.061 (95\% CI: 0.023-0.151)] samples (GLM: $\left.\mathrm{F}_{1,386}=0.74, P=0.390\right)$.

Although the data do not indicate any obvious differences between island and mainland samples for any of the low prevalence pathogens (Table 2), all three ticks that were positive for B. miyamotoi were sampled from Ruissalo Island.

Co-occurrences of two or more bacterial or protozoan pathogen species were detected for nearly $8 \%$ (35/449) of the screened samples and for nearly $16 \%(35 / 223)$ of the ticks that carried pathogens of any kind (singly or co-occurrence). Numerous different co-occurring combinations were observed in the nymphal and adult stages (Online Resource 3 ). Interestingly, over half $(5 / 9)$ of the detections of $C . \mathrm{N}$. mikurensis in the nymphal stage were co-occurrences with other bacterial pathogens, and in four ticks, the cooccurrence was with $B$. afzelii (only 0.8 such ticks can be expected under the independence assumption). The probability of co-occurrence for all the pathogen detections did not differ overall between the island [0.151 (95\% CI: $0.105-$ $0.211), 27 / 178]$ and the mainland [0.182 (95\% CI: $0.093-$ $0.324), 8 / 44]$ samples (GLM: $\left.F_{1,221}=0.26, P=0.614\right)$.

\section{Discussion}

A relatively high pathogen diversity with almost all established and putative tick-borne pathogens of northern Europe was found in I. ricinus ticks thriving in urbanized areas of Turku city. The highest pathogen prevalence was obtained for bacteria in the B. burgdorferi s.l. group (37\% for nymphs and $49 \%$ for adults). The prevalence therein was even higher than that recently reported for Finland, the neighbouring countries of Sweden and Estonia and the rest of Europe in general (Geller et al. 2013; Wilhelmsson et al. 2013a; Sormunen et al. 2016b; Laaksonen et al. 2017; Strnad et al. 2017). In comparison to the situation that prevailed 4 17 years earlier, we found the tick in the grassy edges of maintained city parks and other urban sites with central locations in the city. However, ticks were clearly most abundant in forested patches of suburban islands and uncared-for "backyards" of the university campus area close to the city centre.

\section{Tick and host animal abundance in the city}

Tick densities have been rising overall in northern Europe (see Introduction). In addition, the tick distribution range has spread 300-400 km up to the Arctic Circle in Finland during the past few decades (Öhman 1961; Laaksonen et al. 2017). Compared to previous investigations in Turku (Mäkinen et al. 2003; Sormunen et al. 2016b), a greater-than-tenfold increase was observed for I. ricinus abundance, and this time we found occasional ticks also in city parks in the grid-planned centre.

Thriving I. ricinus populations need maintenance hosts for each life stage. The circulation of pathogens is possible when sufficient reservoir hosts are available (Rizzoli et al. 2014). Despite the locations of the study areas being in close proximity to one another, and hence having highly similar climatic conditions, there are some noteworthy differences between the island and mainland sites concerning tick host animals. On the islands, roe deer (Capreolus capreolus), white-tailed deer (Odocoileus virginianus) and raccoon dogs (Nyctereutes procyonoides) have become abundant enough in recent years to warrant a culling campaign by city officials. By contrast, our mainland study areas are largely devoid of deer and raccoon dogs. All the study areas are inhabited by many birds, rodents (Microtus agrestis, Myodes glareolus and Apodemus flavicollis), European hedgehog (Erinaceus europaeus), shrews (Sorex spp.), European hare (Lepus europaeus), European badger (Meles meles), and even predators such as red fox (Vulpes vulpes) and mustelids (Mustela erminea and M. nivalis) (e.g. Lappalainen and Vuorisalo 1996; Laine and Lehikoinen 2013; Tirri and Vösa 2015). Unfortunately, we do not have relevant data to connect the tick observations from the summer of 2017 to the specific host animal abundance that prevailed in distinct tick sampling areas at that time (and during some earlier years to account for the long life cycle of the tick).

\section{Tick-borne pathogens in the city}

As expected the prevalence of B. burgdorferi s.l. was higher in adult $(49 \%)$ than that in nymph $(37 \%)$ samples. In contrast to many other studies, we also detected one positive larva. Because transovarial transmission can occur for B. burgdorferi s.l., B. miyamotoi (van Duijvendijk et al. 2016) and, e.g., for Rickettsia (see below), larval bites cannot be ignored as possible risk factors for humans.

Most of the pathogens were detected at approximately equal prevalence in island and mainland samples. However, B. burgdorferi s.l. was detected more often in island samples, mostly due to one genospecies, $B$. garinii, which was detected in $11 \%$ of the island nymphs but was relatively rare $(5 \%)$ in mainland ticks. While the exact reasons for this phenomenon cannot be determined, this observation may be linked to song birds and their status as favoured reservoir hosts of $B$. garinii (Kurtenbach et al. 2002; Taragel'ová et al. 2008; Jahfari et al. 2017; Millins et al. 2018). Overall, the densities of most bird species are higher in the more natural, semi-urban environments of Ruissalo and Hirvensalo than those in the maintained and structured environments of the city centre. Along with dozens of other species (Laine and Lehikoinen 2013), commonly reported bird hosts of ticks, namely, thrushes (Turdus spp.) and European robins (Erithacus rubecula) (Taragel'ová et al. 2008; Marsot et al. 2012; Heylen et al. 2017), are 


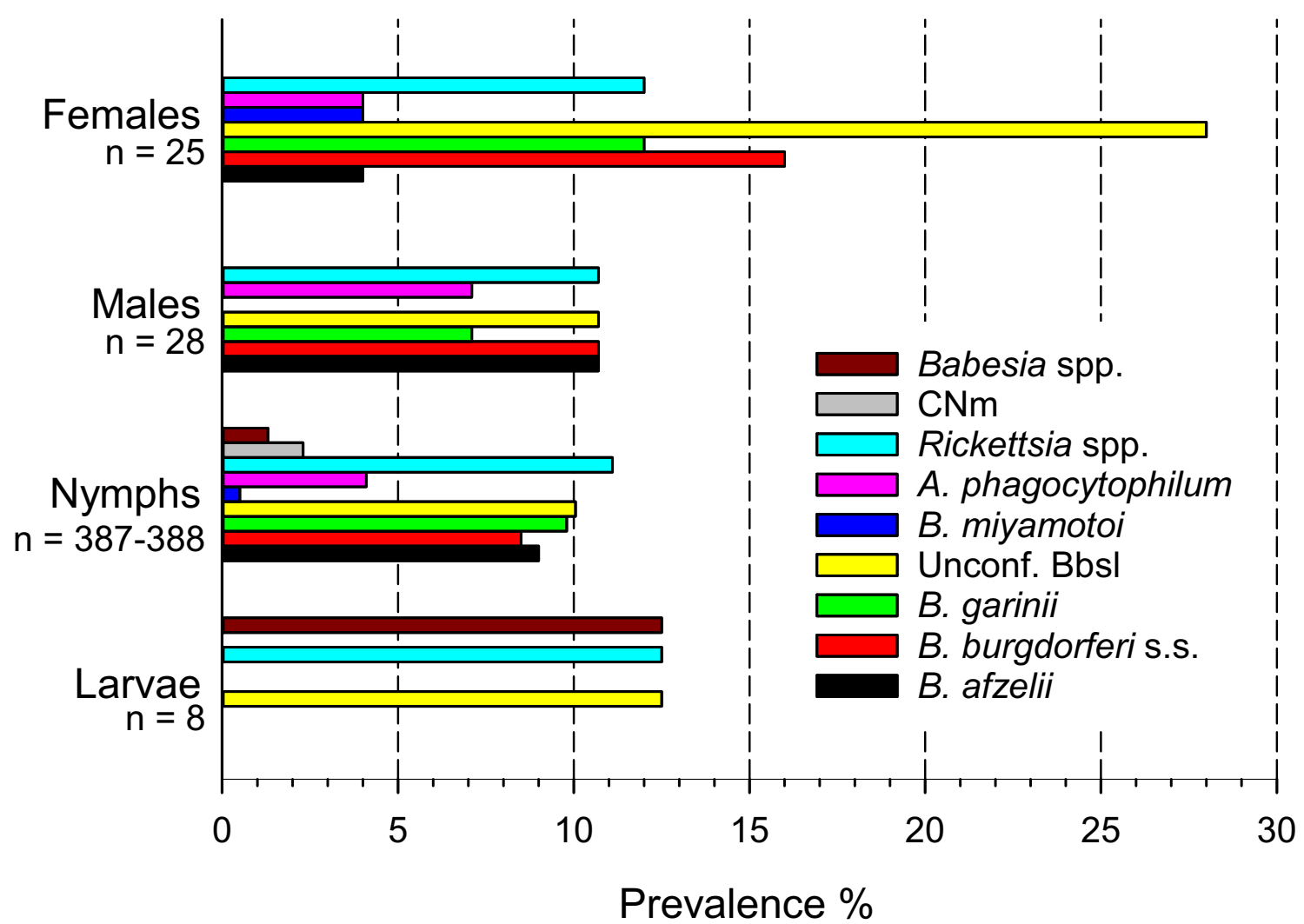

Fig. 2 Prevalence (\%) of bacterial and protozoan (Babesia) pathogen detections among larvae, nymphs, adult males and adult females of Ixodes ricinus ticks collected via cloth-dragging in Turku city, SW Finland, from late May to early July 2017. Occurrences of multiple pathogens were also observed in a single tick. The abbreviations 'Unconf.

abundant nesting birds on the islands. While the same species also inhabit more urban areas of Turku, such as the university campus area (Tirri and Vösa 2015), their role as tick hosts
Bbsl' and 'CNm' denote unconfirmed genospecies in the Borrelia burgdorferi sensu lato group and the bacterium Candidatus Neoehrlichia mikurensis, respectively. Note the low samples size (n) for screened larvae.

might be less common there, for example, because of more patchily distributed habitats and because of thrushes, which tend to forage on maintained park lawns that are not humid

Table 2 Numbers [prevalence \%] of bacterial and protozoan (Babesia) pathogen detections among larvae, nymphs, adult males and adult females of Ixodes ricinus ticks that were cloth-dragged in islands (Ruissalo and Hirvensalo) and in mainland sites

\begin{tabular}{|c|c|c|c|c|c|c|c|c|c|c|}
\hline Stage & $\mathrm{n}^{\mathrm{a}}$ & B. afzelii & $\begin{array}{l}\text { B. burgdorferi } \\
\text { s.s. }\end{array}$ & B. garinii & $\begin{array}{l}\text { Unconf. } \\
\text { Bbsl }^{\mathrm{b}}\end{array}$ & B. miyamotoi & A. phagocytophilum & $\begin{array}{l}\text { Rickettsia } \\
\text { spp. }\end{array}$ & $\mathrm{CNm}^{\mathrm{c}}$ & $\begin{array}{l}\text { Babesia } \\
\text { spp. }\end{array}$ \\
\hline \multicolumn{11}{|l|}{ Islands } \\
\hline Larvae & 3 & $0[0 \%]$ & $0[0 \%]$ & $0[0 \%]$ & $0[0 \%]$ & $0[0 \%]$ & $0[0 \%]$ & $0[0 \%]$ & $0[0 \%]$ & $1[33.3 \%]^{\mathrm{d}}$ \\
\hline Nymphs & $321-322$ & $31[9.6 \%]$ & $27[8.4 \%]$ & $35[10.9 \%]$ & $35[10.9 \%]$ & $2[0.6 \%]$ & $12[3.7 \%]$ & $30[9.4 \%]$ & $8[2.5 \%]$ & $4[1.3 \%]$ \\
\hline Males & 12 & $2[16.7 \%]$ & $2[16.7 \%]$ & $1[8.3 \%]$ & $0[0 \%]$ & $0[0 \%]$ & $1[8.3 \%]$ & $2[16.7 \%]$ & $0[0 \%]$ & $0[0 \%]$ \\
\hline Females & 13 & $0[0 \%]$ & $2[15.4 \%]$ & $2[15.4 \%]$ & $5(38.5 \%]$ & $1[7.7 \%]$ & $1[7.7 \%]$ & $2[15.4 \%]$ & $0[0 \%]$ & $0[0 \%]$ \\
\hline Total & $349-350$ & $33[9.4 \%]$ & $31[8.9 \%]$ & $38[10.9 \%]$ & $40[11.4 \%]$ & $3[0.9 \%]$ & $14[4.0 \%]$ & $34[9.7 \%]$ & $8[2.3 \%]$ & $5[1.4 \%]$ \\
\hline \multicolumn{11}{|l|}{ Mainland } \\
\hline Larvae & 5 & $0[0 \%]$ & $0[0 \%]$ & $0[0 \%]$ & $1[20.0 \%]^{\mathrm{d}}$ & $0[0 \%]$ & $0[0 \%]$ & $1[20.0 \%]^{\mathrm{d}}$ & $0[0 \%]$ & $0[0 \%]$ \\
\hline Nymphs & 66 & $4[6.1 \%]$ & $6[9.1 \%]$ & $3[4.6 \%]$ & $4[6.1 \%]$ & $0[0 \%]$ & $4[6.1 \%]$ & $13[19.7 \%]$ & $1[1.5 \%]$ & $1[1.5 \%]$ \\
\hline Males & 16 & $1[6.3 \%]$ & $1[6.3 \%]$ & $1[6.3 \%]$ & $3[18.8 \%]$ & $0[0 \%]$ & $1[6.3 \%]$ & $1[6.3 \%]$ & $0[0 \%]$ & $0[0 \%]$ \\
\hline Females & 12 & $1[8.3 \%]$ & $2[16.7 \%]$ & $1[8.3 \%]$ & $2(16.7 \%]$ & $0[0 \%]$ & $0[0 \%]$ & $1[8.3 \%]$ & $0[0 \%]$ & $0[0 \%]$ \\
\hline Total & 99 & $6[6.1 \%]$ & $9[9.1 \%]$ & $5[5.1 \%]$ & $10[10.1 \%]$ & $0[0 \%]$ & $5[5.1 \%]$ & $16[16.2 \%]$ & $1[1.0 \%]$ & $1[1.0 \%]$ \\
\hline
\end{tabular}

${ }^{\text {a }}$ Sample size of screened ticks in each developmental stage

${ }^{\mathrm{b}}$ Unconfirmed genospecies of Borrelia burgdorferi sensu lato group

${ }^{\mathrm{c}}$ Bacterium Candidatus Neoehrlichia mikurensis

${ }^{\mathrm{d}}$ Note the low sample size for screened larvae 
enough for tick questing. Hence, reduced contacts between ticks needing reservoir hosts, for whatever reasons, may inhibit the establishment of $B$. garinii in urban city environments. This observation serves as an interesting example of the impact of the landscape structure and the small spatial grain at which the occurrence of pathogens may vary (Millins et al. 2018; Sormunen et al. 2018).

Interestingly, in contrast to B. burgdorferi s.l., Rickettsia (mostly R. helvetica) bacteria were detected considerably more often in mainland nymphs than in their island counterparts. As discussed above, differences in the available host animals and the spatially fragmented habitats available in urban areas may have an effect. Because high nymphal Rickettsia prevalence is likely a consequence of a higher proportion of tick larvae feeding on infected reservoir hosts [although the transovarial transmission of Rickettsia has also been documented (Burgdorfer et al. 1979; Azad and Beard 1998; Sprong et al. 2009)], the higher infection rate on the mainland is likely caused by differences in larval host utilization. Further studies in the form of blood meal analyses are planned to determine the identity of the larval blood meals of infected nymphs, and, subsequently, the source of the high Rickettsia prevalence in urban I. ricinus nymphs.

Because the prevalence of TBEV in I. ricinus is typically 0.5-2\% in Finland (Jääskeläinen et al. 2010, 2016), it is not unexpected that we did not find that pathogen in the relatively small subsample (157 ticks) that was extracted for RNA. The large archipelago around Turku and the Åland Islands are known risk areas for TBE (Tonteri et al. 2015). According to the National Infectious Diseases Register (which is maintained by the National Institute for Health and Welfare), approximately 10-20 people contract TBE in Turku or nearby areas every year (Tonteri et al. 2015), in spite of the relatively high vaccination coverage against TBE in these areas. Furthermore, as TBE cases have emerged and novel TBEV foci have been found in new areas (Tonteri et al. 2015; Jääskeläinen et al. 2016; Sormunen et al. 2018), the possible current or future presence of TBEV in the city of Turku cannot be overlooked.

Co-infections with different tick-borne pathogens may result in unpredictable and severe diseases in humans (Swanson et al. 2006). In our samples, several different pathogen combinations were found. $C$. N. mikurensis seemed to co-occur with $B$. afzelii more frequently than expected under random co-occurrence. This higher-thanexpected prevalence has been found several times before for this particular pathogen combination (Andersson et al. 2013; Glatz et al. 2014; Kjelland et al. 2018; Laaksonen et al. 2018; Sormunen et al. 2018), and the finding seems to be associated with wild rodents (especially with the bank vole, Myodes glareolus) that act as common reservoir hosts for both pathogens (Andersson and Råberg 2011; Andersson et al. 2014).

\section{Conclusion}

In the city of Turku, SW Finland, mice, voles, squirrels, shrews, and song birds likely feed tick larvae, whereas European hares, raccoon dogs, foxes and deer at the least are potential hosts for nymphs and adults. European hedgehogs might be potential hosts for all life stages, and they deserve further attention (see Földvári et al. 2011). Both the roe deer and raccoon dog abundances have increased during the last two decades, and at present, they are common on islands and (semi-) rural areas around the city. Although our sample size was only moderate, we detected all the common tick-borne pathogens that are frequently associated with I. ricinus in Europe, apart from TBEV. For two pathogens, B. burgdorferi s.l. and Rickettsia spp., the prevalence was high in urban ticks when compared to the (mean) values reported elsewhere in Finland.

We conclude that $I$. ricinus ticks are present in most of the urban and suburban areas in the city of Turku, and they are especially abundant on Ruissalo Island, which is the most popular area for outdoor recreational activities within the city. These ticks are numerous in other urban areas in Finland as well (Junttila et al. 1999; Laaksonen et al. 2017). These findings highlight the importance of raising awareness of ticks in urban areas, where citizens may generally still believe that the tick risk is minimal. The high prevalence of pathogens, especially B. burgdorferi s.l., together with a large human population and spatially varying tick densities, poses a considerable risk of tick-borne diseases in the city of Turku. The possibility that a person will be infected even within a city centre, not only in southern Finland but across most of Europe, should be acknowledged by local and national health care professionals.

Acknowledgements Open access funding provided by University of Turku (UTU) including Turku University Central Hospital. We thank Anu Jääskeläinen and Elina Tonteri (Department of Virology, University of Helsinki, Finland) for providing TBEV strains to use as positive controls and Ritva Penttinen (Zoological Museum, University of Turku, Finland) for comments on the manuscript. We thank biology students Antti Kukkula, Pauliina Pajala, Saku Partanen, Anna Puisto and Ella Sippola for assistance in the lab and field. This study was financially supported by a grant from the Jane and Aatos Erkko Foundation to the research team and by the University of Turku Graduate School (Doctoral Programme in Biology, Geography and Geology) to J.J.S.

Open Access This article is distributed under the terms of the Creative Commons Attribution 4.0 International License (http:// creativecommons.org/licenses/by/4.0/), which permits unrestricted use, distribution, and reproduction in any medium, provided you give appropriate credit to the original author(s) and the source, provide a link to the Creative Commons license, and indicate if changes were made. 


\section{References}

Alekseev AN, Dubinina HV, Jääskeläinen AE, Vapalahti O, Vaheri A (2007) First report on tick-borne pathogens and exoskeletal anomalies in Ixodes persulcatus Schulze (Acari: Ixodidae) collected in Kokkola coastal region, Finland. Int J Acarol 33:253-258. https:// doi.org/10.1080/01647950708684530

Alkishe AA, Peterson AT, Samy AM (2017) Climate change influences on the potential geographic distribution of the disease vector tick Ixodes ricinus. PLoS One 12:e0189092. https://doi.org/10.1371/ journal.pone. 0189092

Andersson M, Råberg L (2011) Wild rodents and novel human pathogen Candidatus Neoehrlichia mikurensis, southern Sweden. Emerg Infect Dis 17:1716-1718. https://doi.org/10.3201/eid1709.101058

Andersson M, Bartkova S, Lindestad O, Råberg L (2013) Co-infection with 'Candidatus Neoehrlichia mikurensis' and Borrelia afzelii in Ixodes ricinus ticks in southern Sweden. Vector Borne Zoonotic Dis 13:438-442. https://doi.org/10.1089/vbz.2012.1118

Andersson M, Scherman K, Råberg L (2014) Infection dynamics of the tick-borne pathogen 'Candidatus Neoehrlichia mikurensis' and coinfections with Borrelia afzelii in bank voles in southern Sweden. Appl Environ Microbiol 80:1645-1649. https://doi.org/ 10.1128/AEM.03469-13

Azad AF, Beard CB (1998) Rickettsial pathogens and their arthropod vectors. Emerg Infect Dis 4:179-186. https://doi.org/10.3201/ eid0402.980205

Burgdorfer W, Aeschlimann A, Peter O, Hayes SF, Philip RN (1979) Ixodes ricinus: vector of a hitherto undescribed spotted fever group agent in Switzerland. Acta Trop 36:357-367

Estrada-Peña A, de la Fuente J (2014) The ecology of ticks and epidemiology of tick-borne viral diseases. Antivir Res 108:104-128. https:// doi.org/10.1016/j.antiviral.2014.05.016

Estrada-Peña A, Mihalca AD, Petney TN, eds. (2017) Ticks of Europe and North Africa: a guide to species identification. Springer. https:// doi.org/10.1007/978-3-319-63760-0

Földvári G, Rigó K, Jablonszky M, Biró N, Majoros G, Molnár V, Tóth M (2011) Ticks and the city: Ectoparasites of the northern white-breasted hedgehog (Erinaceus roumanicus) in an urban park. Ticks TickBorne Dis 2:231-234. https://doi.org/10.1016/j.ttbdis.2011.09.001

Geller J, Nazarova L, Katargina O, Golovljova I (2013) Borrelia burgdorferi sensu lato prevalence in tick populations in Estonia. Parasit Vectors 6:202. https://doi.org/10.1186/1756-3305-6-202

Glatz M, Müllegger RR, Maurer F, Fingerle V, Achermann Y, Wilske B, Bloemberg GV (2014) Detection of Candidatus Neoehrlichia mikurensis, Borrelia burgdorferi sensu lato genospecies and Anaplasma phagocytophilum in a tick population from Austria. Ticks Tick-Borne Dis 5:139-144. https://doi.org/10.1016/j.ttbdis. 2013.10.006

Hassell JM, Begon M, Ward MJ, Févre EM (2017) Urbanization and disease emergence: dynamics at the wildlife-livestock-human interface. Trends Ecol Evol 32:55-67. https://doi.org/10.1016/j.tree. 2016.09.012

Heylen D, Krawczyk A, de Carvalho IL, Núncio MS, Sprong H, Norte AC (2017) Bridging of cryptic Borrelia cycles in European songbirds. Environ Microbiol 19:1857-1867. https://doi.org/10.1111/ 1462-2920.13685

Jääskeläinen AE, Sironen T, Murueva GB, Subbotina N, Alekseev AN, Castrén J, Alitalo I, Vaheri A, Vapalahti O (2010) Tick-borne encephalitis virus in ticks in Finland, Russian Karelia and Buryatia. J Gen Virol 91:2706-2712. https://doi.org/10.1099/vir.0.023663-0

Jääskeläinen A, Tonteri E, Pieninkeroinen I, Sironen T, Voutilainen L, Kuusi M, Vaheri A, Vapalahti O (2016) Siberian subtype tick-borne encephalitis virus in Ixodes ricinus in a newly emerged focus, Finland. Ticks Tick-Borne Dis 7:216-223. https://doi.org/10.1016/ j.ttbdis.2015.10.013
Jaenson TGT, Hjertqvist M, Bergström T, Lundkvist $\AA$ (2012) Why is tick-borne encephalitis increasing? A review of the key factors causing the increasing incidence of human TBE in Sweden. Parasit Vectors 5:184. https://doi.org/10.1186/1756-3305-5-184

Jahfari S, Krawczyk A, Coipan EC, Fonville M, Hovius JW, Sprong H, Takumi K (2017) Enzootic origins for clinical manifestations of Lyme borreliosis. Infect Genet Evol 49:48-54. https://doi.org/10. 1016/j.meegid.2016.12.030

Jore S, Vanwambeke SO, Viljugrein $\mathrm{H}$, Isaksen $\mathrm{K}$, Kristoffersen $\mathrm{AB}$, Woldehiwet Z, Johansen B, Brun E, Brun-Hansen H, Westermann S, Larsen I-L, Ytrehus B, Hofshagen M (2014) Climate and environmental change drives Ixodes ricinus geographical expansion at the northern range margin. Parasit Vectors 7:11. https://doi.org/10. 1186/1756-3305-7-11

Junttila J, Peltomaa M, Soini H, Marjamäki M, Viljanen MK (1999) Prevalence of Borrelia burgdorferi in Ixodes ricinus ticks in urban recreational areas of Helsinki. J Clin Microbiol 37:1361-1365

Kjelland V, Paulsen KM, Rollum R, Jenkins A, Stuen S, Soleng A, Edgar KS, Lindstedt HH, Vaino K, Gibory M, Andreassen ÅK (2018) Tick-borne encephalitis virus, Borrelia burgdorferi sensu lato, Borrelia miyamotoi, Anaplasma phagocytophilum and Candidatus Neoehrlichia mikurensis in Ixodes ricinus ticks collected from recreational islands in southern Norway. Ticks Tick-Borne Dis 9:10981102. https://doi.org/10.1016/j.ttbdis.2018.04.005

Kowalec M, Szewczyk T, Welc-Falęciak R, Siński E, Karbowiak G, Bajer A (2017) Ticks and the city - are there any differences between city parks and natural forests in terms of tick abundance and prevalence of spirochaetes? Parasit Vectors 10(573):573. https://doi.org/ 10.1186/s13071-017-2391-2

Kurtenbach K, De Michelis S, Etti S, Schäfer SM, Sewell HS, Brade V, Kraiczy P (2002) Host association of Borrelia burgdorferi sensu lato - the key role of host complement. Trends Microbiol 10:74-79. https://doi.org/10.1016/S0966-842X(01)02298-3

Laaksonen M, Sajanti E, Sormunen JJ, Penttinen R, Hänninen J, Ruohomäki K, Sääksjärvi I, Vesterinen EJ, Vuorinen I, Hytönen J, Klemola T (2017) Crowdsourcing-based nationwide tick collection reveals the distribution of Ixodes ricinus and I. persulcatus and associated pathogens in Finland. Emerg Microbes Infect 6:e31. https://doi.org/10.1038/emi.2017.17

Laaksonen M, Klemola T, Feuth E, Sormunen JJ, Puisto A, Mäkelä S, Penttinen R, Ruohomäki K, Hänninen J, Sääksjärvi IE, Vuorinen I, Sprong H, Hytönen J, Vesterinen EJ (2018) Tick-borne pathogens in Finland: comparison of Ixodes ricinus and I. persulcatus in sympatric and parapatric areas. Parasit Vectors 11:556. https://doi.org/10. 1186/s13071-018-3131-y

Laine J, Lehikoinen E (2013) Ruissalon linnusto ja sen muutokset [avifauna of Ruissalo and its changes], in Finnish. Ukuli 44:25-40

Lappalainen M, Vuorisalo T (1996) Kaikenkarvaiset kaupunkilaiset: Turun nisäkkäät [The wild mammals of Turku], in Finnish with English abstract. TS-Yhtymä Oy, Turku

Lindblom A, Wallménius K, Sjöwall J, Fryland L, Wilhelmsson P, Lindgren P-E, Forsberg P, Nilsson K (2016) Prevalence of Rickettsia spp. in ticks and serological and clinical outcomes in tick-bitten individuals in Sweden and on the Åland Islands. PLoS One 11:e0166653. https://doi.org/10.1371/journal.pone.0166653

Mäkinen J, Vuorinen I, Oksi J, Peltomaa M, He QS, Marjamäki M, Viljanen MK (2003) Prevalence of granulocytic Ehrlichia and Borrelia burgdorferi sensu lato in Ixodes ricinus ticks collected from southwestern Finland and from Vormsi Island in Estonia. APMIS 111:355-362. https://doi.org/10.1034/j.1600-0463.2003.1110209.x

Marsot M, Henry P-Y, Vourc'h G, Gasqui P, Ferquel E, Laignel J, Grysan M, Chapuis J-L (2012) Which forest bird species are the main hosts of the tick, Ixodes ricinus, the vector of Borrelia burgdorferi sensu lato, during the breeding season? Int J Parasitol 42:781-788. https:// doi.org/10.1016/j.ijpara.2012.05.010 
Medlock JM, Leach SA (2015) Effect of climate change on vector-borne disease risk in the UK. Lancet Infect Dis 15:721-730. https://doi. org/10.1016/S1473-3099(15)70091-5

Medlock JM, Hansford KM, Bormane A, Derdakova M, Estrada-Peña A, George J-C, Golovljova I, Jaenson TGT, Jensen J-K, Jensen PM, Kazimirova M, Oteo JA, Papa A, Pfister K, Plantard O, Randolph SE, Rizzoli A, Santos-Silva MM, Sprong H, Vial L, Hendrickx G, Zeller H, Van Bortel W (2013) Driving forces for changes in geographical distribution of Ixodes ricinus ticks in Europe. Parasit Vectors 6(1). https://doi.org/10.1186/1756-3305-6-1

Millins C, Dickinson ER, Isakovic P, Gilbert L, Wojciechowska A, Paterson V, Tao F, Jahn M, Kilbride E, Birtles R, Johnson P, Biek $\mathrm{R}$ (2018) Landscape structure affects the prevalence and distribution of a tick-borne zoonotic pathogen. Parasit Vectors 11:621. https:// doi.org/10.1186/s13071-018-3200-2

Mills JN, Gage KL, Khan AS (2010) Potential influence of climate change on vector-borne and zoonotic diseases: a review and proposed research plan. Environ Health Perspect 118:1507-1514. https://doi.org/10.1289/ehp.0901389

Öhman C (1961) The geographical and topographical distribution of Ixodes ricinus in Finland. Acta Soc Fauna Flora Fenn 76:1-38

Pangrácová L, Derdáková M, Pekárik L, Hviščová I, Víchová B, Stanko M, Hlavatá H, Pet'ko B (2013) Ixodes ricinus abundance and its infection with the tick-borne pathogens in urban and suburban areas of eastern Slovakia. Parasit Vectors 6:238. https://doi.org/10.1186/ 1756-3305-6-238

Paul REL, Cote M, Le Naour E, Bonnet SI (2016) Environmental factors influencing tick densities over seven years in a French suburban forest. Parasit Vectors 9:309. https://doi.org/10.1186/s13071-016$1591-5$

Pfäffle M, Littwin N, Muders SV, Petney TN (2013) The ecology of tickborne diseases. Int J Parasitol 43:1059-1077. https://doi.org/10. 1016/j.ijpara.2013.06.009

Rizzoli A, Silaghi C, Obiegala A, Rudolf I, Hubálek Z, Földvári G, Plantard O, Vayssier-Taussat M, Bonnet S, Špitalská E, Kazimírová M (2014) Ixodes ricinus and its transmitted pathogens in urban and peri-urban areas in Europe: new hazards and relevance for public health. Front Public Health 2(251). https://doi.org/10. 3389/fpubh.2014.00251

Sajanti E, Virtanen M, Helve O, Kuusi M, Lyytikäinen O, Hytönen J, Sane J (2017) Lyme Borreliosis in Finland, 1995-2014. Emerg Infect Dis 23:1282-1288. https://doi.org/10.3201/eid2308.161273

Schwaiger M, Cassinotti P (2003) Development of a quantitative realtime RT-PCR assay with internal control for the laboratory detection of tick borne encephalitis virus (TBEV) RNA. J Clin Virol 27:136145. https://doi.org/10.1016/S1386-6532(02)00168-3

Sormunen JJ, Klemola T, Vesterinen EJ, Vuorinen I, Hytönen J, Hänninen J, Ruohomäki K, Sääksjärvi IE, Tonteri E, Penttinen R (2016a) Assessing the abundance, seasonal questing activity, and Borrelia and tick-borne encephalitis virus (TBEV) prevalence of Ixodes ricinus ticks in a Lyme borreliosis endemic area in Southwest Finland. Ticks Tick-Borne Dis 7:208-215. https://doi.org/10.1016/ j.ttbdis.2015.10.011

Sormunen JJ, Penttinen R, Klemola T, Hänninen J, Vuorinen I, Laaksonen M, Sääksjärvi IE, Ruohomäki K, Vesterinen EJ (2016b) Tick-borne bacterial pathogens in southwestern Finland. Parasit Vectors 9:168. https://doi.org/10.1186/s13071-016-1449-x

Sormunen JJ, Penttinen R, Klemola T, Vesterinen EJ, Hänninen J (2016c) Anaplasma phagocytophilum in questing Ixodes ricinus ticks in southwestern Finland. Exp Appl Acarol 70:491-500. https://doi, org/10.1007/s10493-016-0093-7
Sormunen JJ, Klemola T, Hänninen J, Mäkelä S, Vuorinen I, Penttinen R, Sääksjärvi IE, Vesterinen EJ (2018) The importance of study duration and spatial scale in pathogen detection - evidence from a tickinfested island. Emerg Microbes Infect 7:189. https://doi.org/10. 1038/s41426-018-0188-9

Sprong H, Wielinga PR, Fonville M, Reusken C, Brandenburg AH, Borgsteede F, Gaasenbeek C, van der Giessen JWB (2009) Ixodes ricinus ticks are reservoir hosts for Rickettsia helvetica and potentially carry flea-borne Rickettsia species. Parasit Vectors 2:41. https://doi.org/10.1186/1756-3305-2-41

Strnad M, Hönig V, Růžek D, Grubhoffer L, Rego ROM (2017) Europewide meta-analysis of Borrelia burgdorferi sensu lato prevalence in questing Ixodes ricinus ticks. Appl Environ Microbiol 83:e00609e00617. https://doi.org/10.1128/AEM.00609-17

Stroup WW (2013) Generalized linear mixed models: modern concepts, methods and applications. CRC Press, Boca Raton

Swanson SJ, Neitzel D, Reed KD, Belongia EA (2006) Coinfections acquired from Ixodes ticks. Clin Microbiol Rev 19:708-727. https://doi.org/10.1128/CMR.00011-06

Taragel'ová V, Koči J, Hanincová K, Kurtenbach K, Derdáková M, Ogden NH, Literák I, Kocianová E, Labuda M (2008) Blackbirds and song thrushes constitute a key reservoir of Borrelia garinii, the causative agent of Borreliosis in Central Europe. Appl Environ Microbiol 74:1289-1293. https://doi.org/10.1128/aem.01060-07

Tirri I-S, Vösa R (2015) Turun Yliopistonmäen pesimälinnuston kartoitus [nesting birds in the university hill of Turku], in Finnish. Ukuli 46: $10-13$

Tonteri E, Kurkela S, Timonen S, Manni T, Vuorinen T, Kuusi M, Vapalahti O (2015) Surveillance of endemic foci of tick-borne encephalitis in Finland 1995-2013: evidence of emergence of new foci. Euro Surveill 20:21-30. https://doi.org/10.2807/1560-7917. ES.2015.20.37.30020

Tveten A-K (2013) Prevalence of Borrelia burgdorferi sensu stricto, Borrelia afzelii, Borrelia garinii, and Borrelia valaisiana in Ixodes ricinus ticks from the northwest of Norway. Scand J Infect Dis 45: 681-687. https://doi.org/10.3109/00365548.2013.799288

van Duijvendijk G, Coipan C, Wagemakers A, Fonville M, Ersöz J, Oei A, Földvári G, Hovius J, Takken W, Sprong H (2016) Larvae of Ixodes ricinus transmit Borrelia afzelii and B. miyamotoi to vertebrate hosts. Parasit Vectors 9(97):97. https://doi.org/10.1186/ s13071-016-1389-5

Wahlberg P, Saikku P, Brummer-Korvenkontio M (1989) Tick-borne viral encephalitis in Finland. The clinical features of Kumlinge disease during 1959-1987. J Intern Med 225:173-177. https://doi.org/10. 1111/j.1365-2796.1989.tb00059.x

Wilhelmsson P, Lindblom P, Fryland L, Ernerudh J, Forsberg P, Lindgren P-E (2013a) Prevalence, diversity, and load of Borrelia species in ticks that have fed on humans in regions of Sweden and Åland Islands, Finland with different Lyme borreliosis incidences. PLoS One 8:e81433. https://doi.org/10.1371/journal.pone.0081433

Wilhelmsson P, Lindblom P, Fryland L, Nyman D, Jaenson TGT, Forsberg P, Lindgren P-E (2013b) Ixodes ricinus ticks removed from humans in northern Europe: seasonal pattern of infestation, attachment sites and duration of feeding. Parasit Vectors 6:362. https://doi. org/10.1186/1756-3305-6-362 